\title{
The Mouse That Roared
}

\author{
by Howard Adelman
}

\begin{abstract}
A government study shows that new legislation which has been opposed so strongly and for so long by the refugee support community and has been pushed just as stubbornly and uncompromisingly by the government, will, in fact, have little impact on reducing the number of refugee claims. The return to a safe third country will affect, at the most optimistic estimate, 10 percent of claimants and, likely, far fewer. Further, the numbers of claimants would probably have been reduced by twice as much if legislative measures had been introduced which had the support of most refugee support groups.
\end{abstract}

\section{The "Safe Country" Concept}

New legislation passed recently (Bills C-55 and C-84) was intended to reduce spontaneous arrivals into Canada who claim refugee status by enabling Canadian immigration officers to return many such claimants without a refugee hearing. A key concept in the new legislation is "safe country". The "safe country" provision is intended to keep out of the Canadian refugee claims system: 1) those who have received refugee status in another country; 2) those who have applied for refugee status in another country; and, most importantly, 3) those who could have applied for refugee status in another country. These requirements have been qualified by Ministerial assurances: the concept of a safe country would only be applied where a first country did not exhibit a pattern of discrimination against certain classes of refugee claimants who, if they had claimed refugee status in Canada, would have a reasonable possibility of being successful. Thus, the United States, which has an extremely low rate of acceptance for Salvadoreans and Guatemalans, in comparison to acceptance rates in Canada, would not be considered a safe country with respect to a specific class of claimants - Salvadoreans and Guatemalans.

\section{The Issues}

There are a number of issues that have arisen with respect to the concept of a "safe country." What does the concept mean? Is it a valid principle in terms of the political theory and premises of a liberal state? Is such a concept legally valid given the constitution of Canada? Finally, what is the effect of such a concept in deterring pseudo-refugees and genuine refugees from claiming refugee status in Canada?

\section{The Meaning of "Safe Country"}

"Safe country" means, at the very least, a country which has signed the Geneva Convention and agrees not to refoule refugees who arrive in their country to establish that they are refugees according to the Convention. At one level, a safe country is any country in the world which has agreed in law to accord protection to refugee claimants.

But the legal requirement is not sufficient. The practice of that law must be taken into account. If the American refugee acceptance rate for Guatemalans and Salvadoreans is extremely low, as indicated earlier, and is much higher in
Canada, then, in spite of the law, the U.S. is not a "safe country" for Guatemalans and Salvadoreans. Law and application of the law must both be taken into account.

A third and more difficult issue is the quality of the protection and whether it is equivalent to Canada's. West Germany, for example, may not be able to deter refugee claimants by use of a "safe country" designation since most arrivals in West Germany do not come via other countries which have signed the Geneva Convention. They very often come from East Germany via Berlin. But West Germany has a constitutional provision requiring the admission of refugee claimants from East Germany. One way of deterring refugee claimants may be to require them to live in camps for several years, ostensibly to learn German and become acculturated. Until then, such refugee claimants may not be given an opportunity to work or pursue their education.

The quality of protection, as narrowly defined, is equivalent to that in Canada; refugee claimants are not being returned to the countries where they claimed they were persecuted. But the status of refugee claimants is not equivalent; in this broader sense, the quality of protection is not equivalent. Those who advocated the "safe country" doctrine tended to define refugee protection narrowly. 


\section{The Principle of a "Safe Country"}

Is "safe country" a valid principle? To answer this question it is necessary to ascertain the principle behind the obligation of a country to accept refugees. In summary (see my article in the Journal of Refugee Studies, Vol. 1, No. 1, for a more detailed discussion) the principle states that when the whole world is divided into nation-states, and a primary obligation of a nation-state is to provide protection for its citizens, when any one of those nationstates fails to fulfill that obligation, the other nation-states have an obligation to provide that protection to victims of that failure who land within the jurisdiction of a state which does protect its citizens. The principle is silent as to whether an individual who lacks protection can pick and choose amongst the states which offer protection based on the quality of the protection accorded them as refugee claimants.

However, it would seem contrary to the fundamental principle of the obligation of the nation-state to accord protection for refugee claimants to choose amongst the protective states on the basis of which one provides the best opportunities once given that protection. Such a principle of choice for the refugee would result in refugee claimants shopping around; the country that afforded the best conditions for renewing their lives would attract the greatest number of refugee claimants. This would, in effect, discourage countries from providing good opportunities, since the better the opportunities the more refugee claimants they would attract.

On the other hand, one of the premises behind the obligation to refugees is the rights of an individual. Every individual should have the right to leave his or her country. Every individual should have the right to choose where to live. But, and this is a very important but, the right to choose where one should live is subject to the qualification of the right of any state on behalf of its citizens to control entry into its domain.

Thus, even on liberal premises, a refugee claimant does not have the right to choose a country of asylum and to shop around for the country in which to apply for protection. The premises of the refugee protection system is based on circumstances, not choice. The country in which refugees find themselves cannot refoule them and has an obligation to protect them. Further, the implication of allowing that refugee choice may be that countries are encouraged to lower the quality of protection to discourage spontaneous arrivals; if this is the case, the principle of choice is counterproductive to ensuring a high level of protection.

If; however, the premise of refugee protection is based on circumstances, those circumstances will result in some countries receiving a very large proportion of refugee claimants because of the geographical and historical circumstances of that country. In order to offset circumstances, that country might lower the quality of protection in order to pressure refugee claimants to move onto other countries to claim refugee status.

The result is that the very principles and rules set up to guarantee protection for refugee claimants end up acting as a mechanism to lower the quality of protection.

\section{The Legality of a "Safe-Country" Provision}

There are a number of questions which have been raised about whether denying a potential refugee claimant access to Canada's refugee claims procedure is constitutional on the basis that they could have made a refugee claim in another country. The effect of the new Canadian law is to require a claimant to make a claim in any country which he or she sojourned. (Sojourning is defined by the CEIC study as entering that country and passing through its passport controls and staying more than two days.) The effect of the law is to treat two individuals differently on the basis of what one might or could or should have done elsewhere. The individuals did not commit a criminal act in so doing. They did not fail to comply with any positive Canadian requirements for entry into Canada - obtaining a visa, having certain medical inoculations, etc. A number of constitutional experts argue that, according to the Canadian constitution (and cascs that already have been judged in accordance with that constitution), this form of discrimination will be found to be unconstitutional by the Supreme Court of Canada. Whether this will in fact take place must await a challenge to the new Canadian law.

\section{The Purpose of a "Safe Country" Provision}

In the publicity and speeches of Ministers responsible for introducing the new Canadian legislation, the purported purpose was to keep manifestly unfounded refugee claimants from clogging up the Canadian refugee claims system. Manifestly unfounded claims are not equivalent to claimants who fail to prove the validity of their claims to qualify for refugee status. Of the unproven claims, manifestly unfounded claims are only a portion. Claimants who come from countries with none or very few successful refugee claims make up the overwhelming bulk of manifestly unfounded cases.

A recent study of the Refugee Determination Task Force of Employmeni and Immigration Canada, Refugee Claimants: Analysis of Current Flows to Canada (March 1988), provides documentation to indicate that the new Canadian refugee legislation was not aimed primarily at pseudo-claimants, as was publicly claimed, but at claimants from refugee producing countries who were shopping around for countries which either had a more liberal claims procedure or which offered a higher level of protection. This was the point of the "safe return" provision. And the study explicitly admits this.

The concept of safe return is based on the principle that Canada is not the only country in the world which accords protection to refugee claimants. ... It recognizes that many refugee applicants have sought - or could have sought - first asylum in one or more foreign countries where the quality of protection afforded is equivalent to that offered by Canada. (p. 3)

The statistical results of the study reinforce this position. If one eliminates the cases with no indication of refugee acceptance rates and divides the balance of cases surveyed (1209) into those who come from refugee producing countries with acceptance rates over 50 percent (manifestly founded claims), those who come from refugee producing countries with acceptance rates under 15 percent (manifestly unfounded claims) and place the balance in a sundry column in which the character of the claims is not manifest, only 19 percent of the claims can be classified as manifestly unfounded; 55 percent are manifestly well-founded claims, though, since not all are accepted, not all well-founded claims are successful (see Refugee Claimants: Table 1). 


\begin{tabular}{|ccccccc|}
\hline \multicolumn{7}{|c|}{ Refugee Claimants } \\
Table 1 \\
Manifestly & Manifestly & Non-Manifestly & Totals \\
Unfounded Claims & Founded Claims & Known Claims & \\
Nos. $\%$ & Nos. $\%$ & Nos. $\%$ & Nos. $\%$ \\
$225 \quad 19$ & 667 & 55 & 312.26 & 1209100
\end{tabular}

The statements of the study and the statistics demonstrate clearly that the "safe return" provision of the new legislation was not primarily aimed at eliminating bogus refugee claimants from the system but at refugee claimants who could have made a claim in another country. Individuals from the refugee support community attending a consultation session with government officials and members of parliament almost two years ago arrived at a consensus (the Hawkes model) on how to deter bogus claimants without any of the draconian measures of the new legislation. If the target had only been unwarranted claimants, the compromise adopted would have provided the basis for the new legislation.

\section{The Effectiveness of the "Safe Country" Provision}

The intention of the CEIC study was not, of course, to prove that government propaganda about the purpose of the recent legislation was false, but to provide evidence justifying its legislation. The study concludes,

It is clear that the concept of "safe return" could affect up to $40 \%$ of claimant arrivals, depending upon the range of countries that meet the requirements to be designated as safe for the return of asylum seekers. As a result, it is likely that the "safe return" mechanism will have a substantial impact in controlling the irregular movement of asylum seekers to Canada. (p. 2)

Does the study in fact establish any such thing? To answer the question it is necessary to accept the statistics as published and to ignore some distortions, such as the fact that the sample includes not only refugee claimants, but any person arriving from one of Canada's top ten refugee-claimant source countries even if such individuals did not claim and did not intend to claim refugee status. The study could have published the statistics on the number of individuals coming from refugee-claimant source countries who expressed no intention of claiming refugee status in Canada. But it did not.

Though we must use these statistics with this major assumption, one can note that the effect of this methodological assumption will be first, to inflate the proportion of refugee claimants who arrive with proper documentation (and therefore, who can be sent back to other countries), since, presumably, 100 percent of arrivals not intending to claim refugee status carry proper documentation and second, to distort the statistics that define direct and indirect arrivals and sojourners as a proportion of actual refugee claimants.

Ignore the distortions. The central question is whether the statistics provide evidence that the legislation on "safe country" return is efficacious. The concept of a "safe country" return is the main instrument for keeping refugee claimants out of the refugee claims process in Canada. Ignore the other issues such as the legality and justice of denying entry to the refugee claims process for claimants from refugee producing countries.

To determine whether legisiation is efficacious, it is not sufficient to determine the maximum percentage of cases (the study estimates 40 percent) which will be impacted by the safe country provision. It also requires determining which cases can be deterred without any legislation whatsoever and which cases could have been deterred by other, milder legislation which is acceptable to most parts of the refugee support community as well as the opposition parties. Indeed, milder legislation could have been passed almost two years ago, probably with all party support, and made a major impact on the backlog of cases. Finally, what percentage of cases cannot be deterred because the refugee claimants are undocumented? What percentage of cases cannot be deterred because the refugee claimants arrived in Canada without sojourning (staying over two days) in another country? What percentage of cases cannot be deterred because the country cannot be classified as a safe country for that class of refugee claimant?

\section{The Alternative Use of Visas}

For some of the cases, even mild legislation acceptable to the refugee support community, was not required to deter such claimants. No legislation was required. Two of the countries to which refugee claimants belonged - Nicaragua, with refugee acceptance rates of 19 percent, and Honduras, with 26 percent had no visa requirement at the time of the study. The imposition of a visa, which required no legislation, could have eliminated virtually all of these claims. The study itself provides the evidence. "The flow of Hondurans has decreased to a mere trickle after the imposition of a visa requirement in mid-September." (p. 10)

Thus, to assess the efficaciousness of the legislation, all cases from Nicaragua and Honduras must be eliminated from the study. In the sample of 1440 cases representing over 2000 individuals who arrived in Canada between August 10 and September 27 of 1987, 276 cases should be deducted since they could have been and were deterred by the imposition of visas. This leaves 1164 cases.

Not all countries where the claimants could have claimed refugee status are "safe countries"; in the case of the U.S., there is a low acceptance rate for Guatemalans and Salvadoreans. In Canada, Guatemalans have an acceptance rate of 70 percent and Salvadoreans an acceptance rate of 79 percent; in the U.S. the acceptance rates are less than 3 percent. Thus, Guatemalan and Salvadorean refugees transiting the United States cannot be returned to a "safe country", even though virtually all of these claimants arrive indirectly. (Salvadoreans -95 percent; Guatemalans - 98 percent). Guatemalans and Salvadoreans constitute 10 percent of the total in the sample. If eliminated from the targeted group (i.e., those to be returned to "safe countries"), the new system is left with 1027 of the 1440 sample cases, 71 percent of the case load - not an inconsiderable number.

In effect, the "safe country" provision is ineffective when applied to Central American refugees, either because the U.S. discriminates against them in the refugee claims procedure utilized in the United States or because such claimants 
could have been deterred by other means.

Note, we included only Guatemala and $E 1$ Salvador in the list of those to whom the legislation would be inapplicable because of the way the refugee claims procedure operates in the United States. But as the study notes, "With the possible exception of Nicaragua and Iran, all of these countries produce RSAC acceptance rates which are substantially higher than refugee acceptance rates in the United States." (p. 7, emphasis added) To be accurate we should not only eliminate Guatemala and El Salvador from the list, but also all refugee claimants who arrive from Lebanon (20), Ghana (2), Pakistan (9), Somalia (59) and Sri Lanka (40) who transit the United States. This would reduce the number of cases to which the legislation is applicable to 897 cases or 87 percent of the targetable sample or 62 percent of the total cases.

\section{Applicable Cases - Documented and}

\section{Sojourners}

Assume we do not reduce the applicable cases from 1027 to 897 , we have the following scenario. In order to return potential refugee claimants to third countries where they sojourned and might have made a claim, it is necessary to have "documentary evidence to prove status in such a third country." (p. 10) In this case only 526 were documented, 51 percent of the applicable sample or 37 percent of the total number of cases. Thus, on one ground of eligibility for return to a "safe country" - documentation proving a sojourn in that country - the real target would be reduced dramatically.

But the applicable category of those eligible to return must not only have the documentation to prove they sojourned in a third country, they must have actually sojourned in the country. "A claimant who has sojourned in a third country is considered to have stayed more than two days and not been in transit through that country." (p. 5) "A person could not be returned to a third country where the stopover in that country was solely for the purpose of connecting to a flight from Canada." (p. 4)

Unfortunately, the statistics do not provide a breakdown of those who were both inadequately documented for a return and who sojourned in a third country. Assume that the documented group

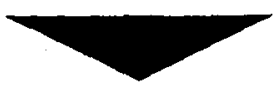

Are the targets of the new legislation manifestly unfounded claimants or claimants from refugee producing countries?

"Seventy percent of the claims aren't genuine. These are people who just want to short cut the normal immigration procedures."

Roger White, CEIC spokesman, Toronto Star, October 7, 1988

"The concept of safe return [the central device in the new legislation to deny claimants access to a hearing] is based on the principle that Canada is not the only country in the world which accords protection to refugee claimants."

Refugee Determination Task Force of Employment and Immigration Canada, "Refugee Claimants: Analysis of Current Flows to Canada" (March 1988)

The scholars in CEIC know who they want to deter even if a CEIC spokesman does not.

was evenly distributed between those who came directly to Canada and those who sojourned in a third country (though it would seem that more of those who sojourned in a third country would arrive without documentation). Of the 1027 cases in the applicable sample, 420 sojourned in third countries. Of the 420 cases, we assume 51 percent had the proper documentation. That is, the "safe country" legislation would be applicable to 214 cases, or about 15 percent of the total cases.

The sample we used included (for purposes of calculation) those who came via the United States. But, according to the study, the acceptance rates in the United States are substantially lower for all but the Iranians. In reality those who sojourned in the U.S. should be taken out of the total. That is, 28 of the 214 cases should be deducted, leaving 186 cases or 13 percent of the targeted group.

\section{Other Factors}

The draconian "safe country" return measure will be applicable to a maximum of 13 percent of the case load. Even this estimate is exaggerated. The total number of cases on which the study was done included all arrivals from countries producing refugee claims, not just those who did file or intended to file a refugee claim. Further, the documented arrivals were distributed evenly between those who arrived in Canada directly and those who had sojourned in a third country, when, in all likelihood, the latter category had a higher percentage of undocumented arrivals.

The total numbers of cases to which the safe return legislation will be applicable is unlikely to exceed 10 percent of refugee claimants. This does not take into consideration that the legislation itsclf is likely to increase those who arrive without documentary evidence to prove status in a third country. Nor does it take into account the possibility that third countrics may not re-admit claimants.

In other words, the maximum of 10 percent of the cases to which the "safe country" return mechanism is applicable, according to past patterns, will be further reduced; of that reduced target there is a strong likelihood that many of the refugee claimants will not be re-admitted to those third countries.

It appears that years of delayed legis- 


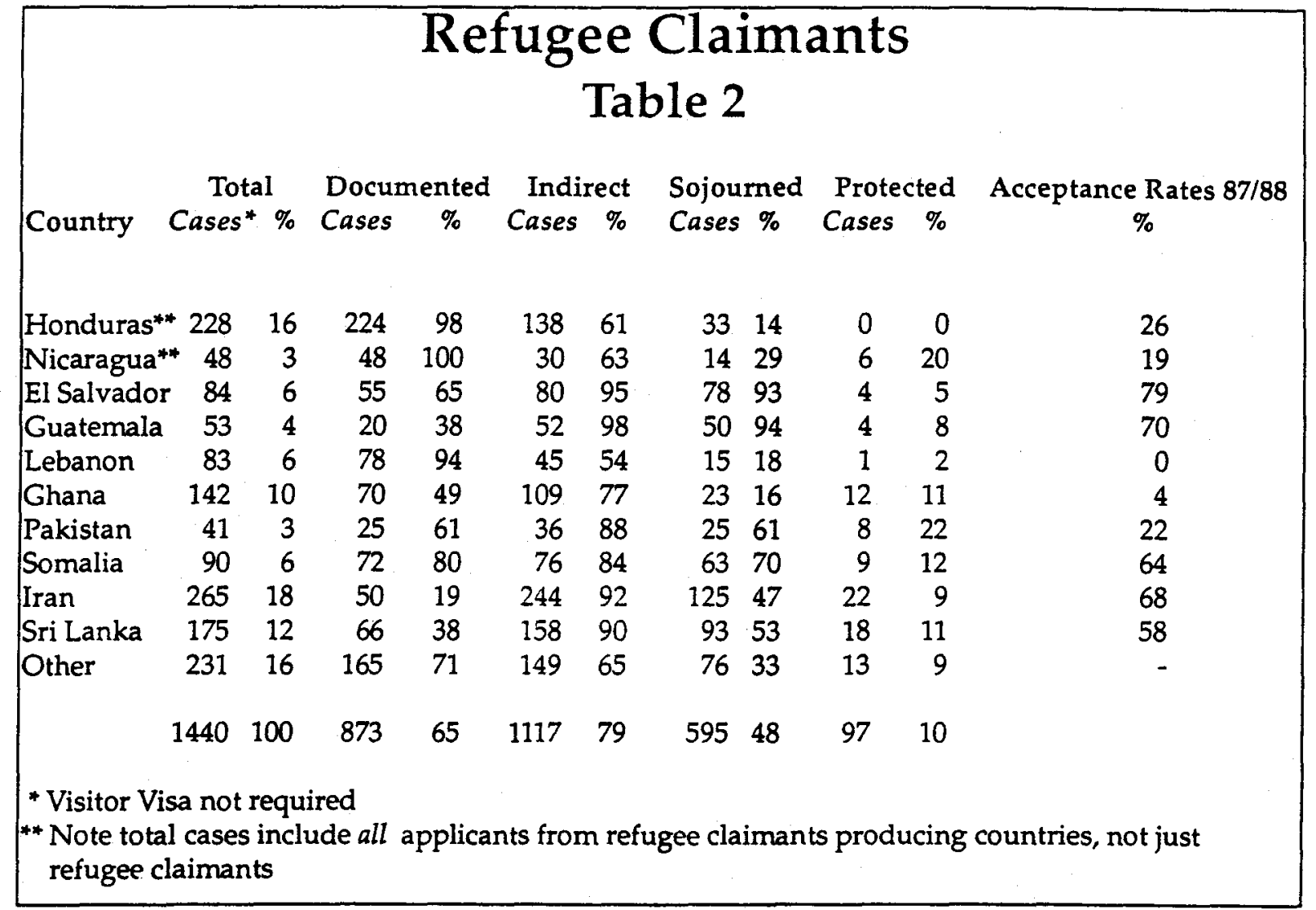

lation and the alienation of the refugee support community, the bulldozing of the opposition parties and the Senate, has resulted in legislation which will do very little to reduce the number of refugee claims.

\section{Alternatives}

One of the measures of efficaciousness is whether a technique of reducing the number of claims is more effective than any alternative. We have tried to indicate that, at the very best, 10 percent of the claimants could be returned to a third country based on the "safe country" criterion. As it happens, the study's statistics indicate that 9 percent of the sample applied for or received refugee status or de facto protection in another country. Several years ago, in the prolonged series of meetings between representatives of refugee support groups, government officials, members of parliament and government ministers, legislation acceptable to most parties would provide for the return of refugee applicants to countries where they had applied for or had received refugee status or de facto protection in that country (provided that country firmly protected the refugee). In other words, legislation acceptable to large numbers of people could have been introduced, probably with unanimous consent, to accomplish a reduction of refugee applicants, by passing legislation which provided for the ineligibility for refugee status in Canada for those who had applied for or received refugee status in another country, providing those claimants had a hearing to determine that the country protected refugees. In other words, eliminating those who could have applied and guaranteeing a hearing to all those who did apply or receive refugee status, would have eliminated the need for a two-stage process that reintroduced complications, alienates the refugee support community, is subject to court challenges and, which, probably won't be effective anyway.

There is one other issue. Ghanaians constitute about 10 percent of the sample. Legislation could have been introduced to define and accelerate the processing of claims from refugee claim countries with very low success rates. This could have been anothe: acceptable method of reducing the number of refugee claims. In other words, alternative and far more acceptable legislation could have been introduced which would have effectively reduced the number of refugee claimants by double the amount that the "safe country" provision is likely to achieve.

\section{Conclusion}

It appears that the "safe country" provision is a mouse that roars. It will have little effect in reducing the number of applicants. Other more specific legislation could have been introduced which would have been effective and more accurately targeted towards those abusing the system while ensuring a fair hearing for all claimants. Instead, time was lost. We now will have a system which will be costly to administer, which will affect very few applicants, and which will be challenged in court in any case. In the process, the refugee support community, whose co-operation is so critical to the successful resettlement of refugees in Canada, has been alienated.

Howard Adelman, a Professor of Philosophy at York University, is the Director of the Refugee Documentation Project and Editor of Refuge. 